NEXHAT KAPIDANI, M.Sc. ${ }^{1}$

E-mail: nexhat.kapidani@pomorstvo.me

EDVARD TIJAN, Ph.D ${ }^{2}$

(Corresponding author)

E-mail: etijan@pfri.hr

MARIJA JOVIĆ, Ph.D. student ${ }^{2}$

E-mail: jovic@pfri.hr

ENIS KOČAN, Ph.D. ${ }^{3}$

E-mail: enisk@ucg.ac.me

${ }^{1}$ Administration for Maritime Safety and Port

Management

Maršal Tito st. 7, PO 14, 85000 Bar, Montenegro

${ }^{2}$ University of Rijeka, Faculty of Maritime Studies

Studentska ulica 2, 51000 Rijeka, Croatia

${ }^{3}$ University of Montenegro, Faculty of Electrical

Enegineering

Dž. Vašingtona bb., 81000 Podgorica, Montenegro
Transport Economics Original Scientific Paper Submitted: 28 Nov. 2019 Accepted: 20 Feb. 2020

\title{
NATIONAL MARITIME SINGLE WINDOW - COST-BENEFIT ANALYSIS OF MONTENEGRO CASE STUDY
}

\begin{abstract}
In this paper, the costs and benefits of the National Maritime Single Window (NMSW) for coastal countries that have limited human resources and infrastructure related to maritime traffic are researched. A general method for conducting a cost-benefit analysis of NMSW implementation is proposed. Using this method and the input data for Montenegro, as an example of a smallsized coastal country, the authors assess whether such an investment in NMSW implementation can be beneficial to coastal countries with limited resources.
\end{abstract}

\section{KEY WORDS}

National Maritime Single Window (NMSW); cost-benefit analysis; Montenegro case study;

\section{INTRODUCTION}

Numerous continuous and often very radical changes occur today in the maritime port service market [1]. The Single Window concept, which enables all stakeholders involved in the business process to input the data and information used by other stakeholders only once (by using a single point of data entry), has significantly changed the methods of information exchange between transport stakeholders, particularly in maritime transport and maritime port business [2]. The Single Window is a national or regional facility mainly built around an ICT platform, initiated by a government or ad hoc authority to facilitate import, export and transit formalities, by offering a single point for the submission of standardized information and documents, in order to meet all the official demands and facilitate logistics [3].

Maritime transport is composed of organizations and activities such as shippers, maritime port stakeholders, and a wide range of professional services around the maritime activities etc. $[4,5]$. In 2018, eleven billion tons of cargo were transported by sea [6]. In this respect, maritime transport also involves a lot of procedures and data that need to be exchanged [7]. The International Maritime Organization Convention on Facilitation of International Maritime Traffic (FAL Convention) plays an essential role in facilitating data exchange in maritime transport, as its main objectives are to prevent unnecessary delays in maritime traffic, to aid co-operation between governments and to secure the highest practicable degree of uniformity in formalities and other procedures $[8,9]$. In this respect, IMO has developed standardized forms, i.e. IMO FAL Forms to simplify the formalities, procedures regarding the arrival and departure of ships and to unify the documents that are requested to be presented to the authorities.

A mandatory requirement for contracting states to IMO FAL Convention (currently 123 states, including Montenegro [10]) to introduce electronic 
information exchange between ships and ports is effective from 8 April 2019. The provision, necessary under IMO (FAL Convention), is part of a package of amendments under the revised Annex to the FAL Convention, adopted in 2016 [11]. The Convention encourages the use of a "single window" for data, to enable all the information required by the public authorities in connection with the arrival, stay and departure of ships, persons and cargo, to be submitted via a single portal, without duplication [11].

National Maritime Single Window (NMSW), also known as the Maritime Single Window, is a place where all information is entered only once and becomes available to various stakeholders [12]. NMSW is an important instrument for facilitating and expediting maritime transport. NMSW is considered primarily to be a business to administration (B2A) system. Seaborne trade could be increasingly affected by the IMO decision to make NMSW mandatory. It could be a potential opportunity for the developing countries, but also a threat if it is not implemented appropriately. Actually, there is a risk that the costs of implementation may be higher than the benefits.

Many endeavors are being undertaken globally to delineate the concept for NMSW and to define the standards and issue recommendations on its implementation [13]. In the early 1980s, the systems based on Electronic Data Interchange (EDI) have been implemented in more significant maritime ports. The aforementioned systems are called Port Community Systems (PCS), and they are still in use in Hamburg - Germany, Felixstowe - UK, Port - MIS in Korea, FCPS in the UK, Portbase in the Netherlands, and others $[14,15]$. The levels of electronic reporting, remote monitoring, and control have rapidly increased in recent years in all industrial fields. Furthermore, new trends and concepts are being developed such as maritime clouds, e-navigation, e-maritime, "maritime Big Data" and the Internet of Things (IoT) that entail both challenges and opportunities for the maritime transport [16-20]. All these trends, even if they are partly overlapping, could lead to digitalization, real-time information [21], and improved connectivity in the maritime transport sector that could not only facilitate shipping, but also improve the energy efficiency, reduce emissions, and develop traffic management and routing.

Undoubtedly, the implementation of the NMSW is a challenging task in terms of costs, complexity, re-engineering of the existing business processes and system maintenance. Dozens of regulations, recommendations and other related documents have to be studied before taking the first steps in the demanding process of the NMSW implementation. This motivated the authors of this paper to provide a comprehensive research of the regulations, recommendations, implementation options, experiences, and expected benefits of deploying the NMSW. More importantly, in this paper the authors provide a method for conducting a cost-benefit analysis of the NMSW implementation, which is general and applicable to any country intending to implement the NMSW. Using the known input data for Montenegro, a cost-benefit analysis of the NMSW implementation and the appropriate concluding remarks are provided. The presented case study could be used as a reference point for different small-size developing countries, which are aware of their limited resources, but are required (or willing) to implement the NMSW.

\section{FRAMEWORK OF SINGLE WINDOWS}

This section aims to analyze and describe the framework of Single Window and the NMSW. The most commonly accepted definition of a Single Window is the one provided by the United Nations Economic Commission for Europe (UNECE) Recommendation No. 33: "a facility that allows parties involved in trade and transport to lodge standardized information and documents with a single-entry point to fulfil all import, export, and transit-related regulatory requirements" [22]. The Single Window concept permits the trader or transporter to submit all the data needed for determining the admissibility of the goods in a standardized format only once. The data should be forwarded to the authorities involved in border controls and at a single portal. It places the onus on the authorities to manage the Single Window and to ensure that the other participating authorities or agencies are either given access to the information or are actually given the data by the managing authority [2]. Furthermore, it eliminates the need for the trader or transporter to submit the same data to several different border authorities or agencies [23].

Single Window may be also considered as a trade facilitator. For UNECE and its UN Centre for Trade Facilitation and Electronic Business (UN/CEFACT), the trade facilitation is "the simplification, standardization and harmonization of 
procedures and associated information flow required to move goods from seller to buyer and to make payment" [24]. Such a definition implies that not only the physical movement of goods is essential in a supply chain, but also the associated information flows. It also encompasses all governmental agencies that intervene in the transit of goods and the various commercial entities that conduct business and move the goods. This is in line with the discussions on trade facilitation currently ongoing at the World Trade Organization [24]. The trade facilitation involves a broad and diverse range of public and private stakeholders seeking to establish a transparent, consistent and predictable environment for border transactions based on standardized and straightforward procedures and practices [25]. In this respect, many countries and international organizations have recognized the numerous benefits of electronic trade facilitation, promoting the development and implementation of trade portals that allow business operators and governments to process the trade information submitted in electronic formats, typically in one place, to all the concerned parties [26].

A National Single Window (NSW) system enables a single submission of electronic documents by the trader such as single data preparation and submission of customs declaration and duty payment for customs release and clearance [27]. The NSW is also a facility that allows parties involved in trade and transport to lodge standardized information and documents with a single-entry point to fulfill all import, export, and transit-related regulatory requirements [28]. The NSW refers to the implementation of a national system that will act as a single point of contact for the electronic submission and exchange of information between public and private stakeholders from different transport modes [29]. It is important to note that the Single Window has evolved from the customs automation era to trade information exchanges, from limited Single Windows connecting traders with a single regulation (e.g. customs, port, etc.) to nationwide NSWs that allow all parties to submit standardized information only once to fulfill all regulatory requirements [30].

As mentioned before, the National Maritime Single Window is similarly defined as a National Single Window: a place where all information is entered only once and becomes available to various stakeholders [12], but related to the maritime environment. Its focus lies on the data associated with vessels, and not the data about cargo and trading.

The NMSW, as an authority operated SW for clearance of ships, should at a minimum cover the handling of IMO FAL data related to the vessel, where general safety and security information regarding the transported cargo is included. Furthermore, the NMSW should be developed to deal with reporting formalities that are the result of international laws that the individual country has acceded at the regional and international levels. Additionally, the NMSW should also cover the information related to the ship clearance which is required by national legislation.

For the past several years, the EU has been working on the development of the European Maritime Single Window - EMSW, with the aim to fully harmonize the interfaces available to operators of ships in order to provide the required information all across the EU [12]. The purpose of EMSW is to standardize the information needed for port management so that the submitted data can be publicly available to all relevant stakeholders [31]. The harmonized EMSW environment for ships will build on the already existing framework (National Single Windows structure) [32]. The National Single Windows will continue to be mainly a coordination mechanism, serving primarily as a router (with technical converter between data formats where needed) to pass the two-way information between the maritime transport operators and the data recipients (e.g. port authorities, customs interfaces and reporting systems, border control authorities, the SafeSeaNet, statistics authorities) with the aim to facilitate reporting for the maritime industry [32].

Due to the strategic importance of creating common regulations for all modes of transport across the Member States, the EMSW has been regarded as a matter of high priority. In 2017, the EU Transport Ministers underlined in the 'Valetta Declaration' the shortcomings of the Reporting Formalities Directive (RFD) and invited the Commission to propose a follow-up to the evaluation of the RFD, which would include a harmonized EMSW environment [33].

At the beginning of 2019, the European Commission signed the agreement with the European Parliament and Council on the implementation of the EMSW, which is expected to enter into force in 2025. Although the deal was well accepted by the 
maritime sector, including the European maritime ports, the ports of Hamburg, Antwerp and Rotterdam have urged the European Transport Committee to vote against the EMSW when an amendment proposal sought to introduce an EU level access point interface, in addition to the new harmonized interface that would be developed at the European level for the NSW [34].

Apart from administrative stakeholders and procedures which fall under the scope of the NMSW, the commercial procedures also need to be handled in an efficient manner. In order to simplify the commercial procedures, a concept of a Port Community System (PCS) was introduced. A PCS is a neutral and open electronic platform enabling an intelligent and secure exchange of information between the public and private stakeholders to improve the competitive position of the sea and airport communities (Figure 1).

The PCS optimizes, manages and automates the port and logistics processes through a single submission of data and connecting transport and logistics chains [36]. The PCS helps stakeholders of the port processes to reduce logistics costs through faster information flow, to deliver the cargo faster, to enable the flow of goods, and finally, to boost the economic growth. As a secondary result, it helps to reduce the externalities such as pollution and harmful emissions [12].

\section{COSTS AND BENEFITS OF NMSW IMPLEMENTATION}

The NMSW is usually developed by the national maritime authorities. For its successful implementation, a selection of the business model is of utmost importance. NMSW business model could be fully developed and funded by the public authorities or by the commercial port companies. For example, the users could finance the NMSW as a fee-per-transaction, as is usually the case with privately operated PCSs [13]. Imposing the fees for the NMSW could be seen as a business barrier and could reduce the competitiveness of ports and countries, as charges will lead to higher transportation costs. Obviously, the no-fee business model requires a commitment to long-term government funding for the implementation and operation of the system [13]. In this section, an overview and quantification of costs of the

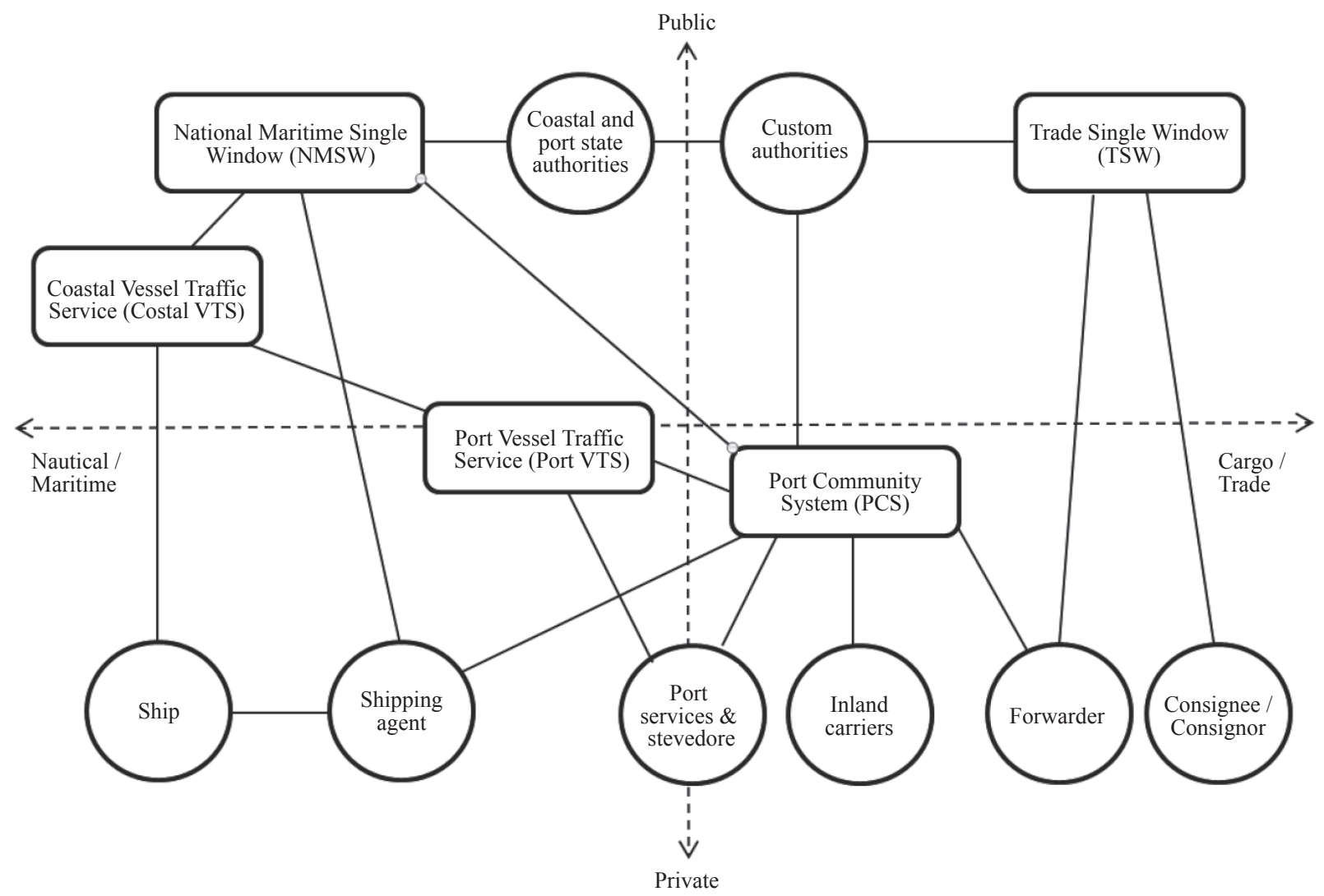

Figure 1-Model of NMSW environment

Source: adapted from [14] and [35] 
NMSW deployment have been provided, as well as the overview and quantification of the NMSW implementation benefits.

\subsection{Costs of NMSW deployment}

The costs of the NMSW deployment could be divided into two principal categories: implementation costs and running costs. Implementation costs could be further divided into preparation costs, technical costs and human resources costs [13].

Preparation costs encompass all costs at the initial phase of NMSW implementation, which is critical for the success. The initial phase should start with establishing a Project Management Group (PMG), which will initiate the first steps and have a lead role during the implementation phase. If the country has previously established a National Facilitation Committee according to the FAL Convention [37], it could also take the role of the PMG. PMG should define the scope of the feasibility study at the very beginning. The study should provide answers to numerous questions such as: what are the project needs, what are the potential benefits of the NMSW services, what is the scope of the NMSW, what are the possible scenarios for implementation, what are the costs, resources and time frame of deployment under the different scenarios, etc. Besides, the feasibility study should identify possible risks and potential benefits of the NMSW application. In addition to the feasibility study, other studies could be used, focusing on particular aspects such as the legal framework, business model, technical issues, business processes, human resources, training, and others. During the preparation phase, a business model should be proposed, which should include the efforts to update the existing regulations to achieve the highest possible harmonization and simplification of procedures. This phase should detect any obsolete or unnecessary regulations and propose their abolishment. The maritime port regulations affect the maritime port efficiency in a non-linear way, and an excess of the rules could have a negative impact on the maritime port efficiency [38].

The overall technical costs of a new NMSW system will be determined by the expenses of the necessary software and hardware investments, as well as by the costs of changes of the existing legacy systems like PCS, etc. Thus, to keep costs down, careful consideration should be given to which legacy systems, processes and information flows should be changed [13]. However, the emphasis should be on the harmonization of processes and data models. The legacy systems are more present in the developed countries than in transition economies such as Montenegro.

Human resources costs are related to the training of end users for using the system and for the preparation of personnel who will be the first level of support and who will deal with the management and basic maintenance of the system. The service level agreement for the maintenance and the extent of "outsourcing" depends on the capabilities of the technical staff of the organization in charge of operating the system. Human resources costs are also related to consultants who are in charge of monitoring the system design and implementation.

Running costs incorporate all the costs after the roll-out and handing over the system to the competent authority, including the maintenance of software and hardware, user support services, communication links, and other operation costs.

According to previous experiences, the total implementation costs could be from less than 1 million US dollars (Guatemala) up to 4 million dollars (Finland, Senegal, Malaysia) or sometimes even more, for example in the US [39].

\subsection{Quantification of costs}

For the purpose of costs quantification, the NMSW is presumed to be an information system with a lifecycle of $N$ years. It is assumed that during the first $N$ years only the running costs will occur, with no additional hardware/software implementation costs. Therefore, overall costs $C$ for $N$ years will be:

$C=P+T+M+\sum_{i=1}^{N} R_{i}$

where $P$ are preparation costs, $T$ are technical costs, $M$ are human resources costs and $R_{i}$ are running costs for each year.

Preparation costs should cover all the expenses related to conducting fundamental/feasibility studies and the preparation of tender documentation that will precede the NMSW implementation. The preparation phase is a paramount step, and the decisions made in this phase will determine the future costs of the NMSW implementation.

Technical costs could be further elaborated depending on how many legacy systems have to be updated (existing PCSs, customs, etc.). Assuming $M$ legacy systems exist, the technical costs can be calculated as follows: 


$$
T=H_{0}+S_{0}+\sum_{j=1}^{M} L_{j}
$$

where $H_{0}$ are hardware costs, $S_{0}$ are software costs and $L_{j}$ are the costs of updating each legacy system for $1 \leq j \leq M$.

Running costs $R_{i}$ present the annual expenses of the NMSW after its implementation. These costs should cover the costs for "in-house" first level support (if there is any) and for outsourcing one or more companies for hardware and software maintenance. These companies will perform second level support.

"In-house" support considers that the National Competent Authority (NCA) for the NMSW employs technically skilled personnel that could provide basic support such as password reset, client configuration and basic hardware and software maintenance. The first level support should gather and analyze information about different end users' issues, and determine the best way to resolve their problems. The advantage of having an "in-house" support team is that the response time is quicker, while the costs of outsourcing contracts will be lower. Costs related to the "in-house" support team are their wages and expenses of their continuous training. Assuming that the NCA is also the authority in charge of other systems like VTMIS (Vessel Traffic Monitoring Information System), AIS (Automatic Identification System), etc, the costs for "in-house" support could be shared, as the same personnel could provide support for various systems. This scenario should be recommended for Montenegro. Otherwise, establishing the new "in-house" support team only for the NMSW is not cost-efficient, and outsourcing should be considered as a more appropriate solution.

Hardware maintenance (according to Gartner IT glossary [40]) includes preventive and corrective services that physically repair or optimize the hardware. It also provides hardware warranty upgrades and technical troubleshooting.

Software maintenance is an integral part of a software lifecycle. It consumes most of the budget during the software lifecycle but is needed for many reasons. It ensures that the software satisfies the end-user requirements, corrects faults, implements enhancements and policy changes, interfaces with other software, etc. Software maintenance should also improve the existing functions, and identify security threats and installation of necessary security patches for vulnerabilities. Besides preventive and corrective software maintenance, it is also required to include adaptive and preventive software maintenance. Adaptive support deals with inevitable future changes if the working environment of software changes. Preventive support will take care of future variations in the software that occurs while adding new modules or functionalities in the software.

Therefore, running costs for year $i$, where $1 \leq i \leq$ $N$ can be formulated as:

$R_{i}=P_{i}+H_{i}+S_{i}$

where $P_{i}$ are costs of "in-house" first level support team, $H_{i}$ costs of second level hardware maintenance support and $S_{i}$ costs of second level software maintenance.

Thus, for the overall costs, the following is provided:

$$
\begin{aligned}
C= & P+T+M+\sum_{i=1}^{N} R_{i}=P+H_{0}+S_{0}+\sum_{j=1}^{M} L_{j}+M+ \\
& +\sum_{i=1}^{N}\left(P_{i}+H_{i}+S_{i}\right)
\end{aligned}
$$

Regarding factors $j$ and $i$, it is possible to observe the difference between the developed and undeveloped countries.

The developed countries, assuming that they have still not implemented an NMSW solution, will have a higher number of legacy systems that need to be updated, while developing countries will have a lesser number (or none) of legacy systems to update.

Factor $\mathrm{i}$ is also correlated with the development of the country. If the state is developing, $N$ should be higher $(15 \leq N \leq 20)$ than for the developed countries $N \leq 15$.

\subsection{Benefits of NMSW implementation}

The implementation of an NMSW can be highly beneficial for both the state where it is deployed and the stakeholders that are involved in maritime transport [41]. The benefits of the NMSW implementation could be numerous, such as increased revenues through more effective and efficient utilization of human and financial resources for the authorized inspections, transparent and predictable interpretation and application of rules, and enhanced safety and security due to improved and preemptive risk management $[25,30]$.

Maritime traders could reduce their costs via NMSW by reducing delays through faster clearance and release of their goods, increased transparency, and predictability of rules. Finally, they could deploy 
their resources more effectively and efficiently as a result of the one-time electronic submission of information [42].

It is estimated that the introduction of EMSW will cost 29.4 million euro between 2020 and 2030 and will directly save from 22 to 25 million staff hours in the 10-year time frame from 2020 to 2030, which is equivalent to a value of 625 to 720 million euro for all EU member states, while indirectly it will also positively affect the shift of transport mode from road to waterborne transport [43]. An electronic document-exchange system for maritime port operations in the port of Hamburg (Germany) saves approximately 22.5 million euro yearly, mainly through the reduction of labour costs [44]. In Senegal, the National Single Window implementation has reduced the average document collecting time from four days to one day. Customs clearance procedures in Cameroon have been reduced from six days to three hours. The total cargo turnover/dwell time in Benin has decreased from 39 days to six days, and in Malaysia from four days to two days [43].

The NMSW will introduce electronic documents that are better structured and more reliable than paper documents. Such documents may assist in risk management, for example, to determine whether a ship is safe or whether it may be carrying contraband goods or similar. The NMSW enhances automated track and tracing systems of ships and cargo, monitoring of document processing, security, and non-repudiation. In some countries, the introduction of improved clearance led to fewer customs and Port State Control (PSC) inspections [45].

The ability of ports to decrease the transport costs is an essential dimension of their competitiveness. The container freight rates between Shanghai and the Mediterranean are around 739 USD and have dropped by $41 \%$ in seven years $(2010-2016)$ [46]. In some maritime ports, the paperwork costs still present a significant share of overall transport costs. A World Bank Report states that improving the trade efficiency could be done through port and customs automation. The average export border compliance time for the ports with no electronic data exchange is almost 100 hours, which is more than double compared to the ports with automatic data exchange [47].

\subsection{Quantification of benefits}

To quantify the benefits of the NMSW implementation, the overall processing time required for each document associated with the port call (arrival and departure) or transit should be determined, before the NMSW implementation $\left(t_{1}\right)$ and after implementation $\left(t_{2}\right)$. The difference between these two working times $\left(t_{d}\right)$ will quantify the time that will be saved after the NMSW deployment for one port call or transit.

$t_{d}=t_{1}-t_{2}$

Saved time, represented in hours, could be multiplied by the average cost per working hour so that the benefit of the NMSW could be quantified. For this purpose, it is assumed that $K$ documents exist that should be handled by $I$ governmental agencies or data providers (agent or ship master). Overall time consumed for managing all these documents for one ship call before the NMSW implementation is equal to:

$t_{1}=\sum_{i=1}^{I} \sum_{j=1}^{K} t_{1}^{i, j}$

Likewise, time spent on processing the paperwork during the ship call after the NMSW implementation will be:

$t_{2}=\sum_{i=1}^{I} \sum_{j=1}^{K} t_{2}^{i, j}$

Furthermore, assuming that an average cost of working hour is $p$, and that the NMSW will serve $V$ number of vessels yearly, overall benefit $B$ for $N$ years could be calculated through:

$$
B=N V p t_{d}=N V p\left(\sum_{i=1}^{I} \sum_{j=1}^{K} t_{1}^{i, j}-\sum_{i=1}^{I} \sum_{j=1}^{K} t_{2}^{i, j}\right)
$$

It is assumed that the NMSW will serve only SOLAS ships. If the NMSW also serves non-SOLAS vessels, that will be an added value feature.

It is also assumed that the NMSW serves $V$ ship calls on an annual basis, out of which $C$ are calls to national ports, while $T$ is the number of transits served by the NMSW annually. Hence:

$V=C+T$

\section{RESEARCH RESULTS AND DISCUSSION}

Montenegro has four ports of national importance, which are open for international traffic: Port of Bar, Marina Bar, Port of Kotor, and Shipyard Bijela [48]. There are other official ports of entry of local importance open for international traffic: Porto Montenegro, Porto Novi, Dukley Marina Budva and Port of Zelenika. 
The Port of Bar is the largest and the crucial port in Montenegro. It can handle dry cargo, liquid cargo, general cargo, cruise ships, and ro-ro ships. The Port of Bar also has a Passenger terminal but is mostly oriented to transport of goods. Almost 95\% of products coming from the sea to Montenegro are transported through this port. Although the Port of Bar alone is designed to handle 5 million tons of cargo, in the last years, the total cargo load in the whole of Montenegro did not exceed 2 million tons on a yearly basis (Table 1). According to data from the Harbour Master Office (HMO) Bar [49], 596 ships called to Port of Bar during 2018, carrying 21,887 passengers and 2,028,172 tons of cargo.

The Port of Kotor has lately become a top-rated cruising destination. The number of cruise ships had almost tripled, while the number of cruise passengers has increased more than tenfold since Montenegro gained independence in the year 2006 [5153], owing to the fact that the size of the cruisers has also increased. According to the data from the Harbour Master Office Kotor [49], 445 ships called to the port of Kotor and other ports in the Boka Bay during 2018, with 493,444 passengers and 1,276 tons of cargo.

The Marina Bar is dominantly oriented to pleasure crafts, as other points of entry of local importance, while the Shipyard Bijela is in the process of transformation. The HMO Bar issued 1,494 vignettes, while the HMO Kotor issued 3,582 vignettes to foreign pleasure yachts that arrived in the Montenegro ports [49].
More comprehensive and accurate data with a total throughput of maritime traffic in the last twelve years in Montenegro is shown in Table 1, as it will be a valuable input for the NMSW concept planning.

It should be emphasized that the MontStat and HMO data on maritime traffic are incoherent. Implementing the NMSW could remove the inconsistencies in data collected by different institutions using different methods and criteria.

As maritime administration and arrival/departure procedures are carried out similarly in Croatia, the steps in the implementation process are explained through the case of the Croatian NSW. Two studies were produced in Croatia in order to enable successful NSW implementation (in 2011 and 2017). Several issues slowed down the implementation of the Croatian NSW: less cooperative stakeholders (who mostly own and operate separate ICT systems), insufficient government support, and financial issues. In the meantime, the Croatian Ministry of the Sea, Transport and Infrastructure has developed a unique Maritime Single Window system (CIMIS) that implements all national-level processes related to the administrative aspect and aspect of navigation safety. In order for CIMIS to be able to exchange data with external systems, a new service CIMISNet has been established, which aims to improve data exchange, reduce administrative procedures among all Port authorities, various Ministries, the Customs administration, Coastal Shipping Agency, Croatian Bureau of Statistics, etc. [2].

Table 1 - Montenegro maritime traffic data for the period 2007-2018 [50-52]

\begin{tabular}{||c|c|c|c|c|c|c||}
\hline \multirow{2}{*}{ Year } & \multicolumn{7}{|c|}{ Maritime traffic } \\
\cline { 2 - 7 } & $\begin{array}{c}\text { Passengers in } \\
\text { ports }\end{array}$ & $\begin{array}{c}\text { Turnover in ports } \\
\text { in tons }\end{array}$ & Foreign yachts & $\begin{array}{c}\text { Passengers on } \\
\text { foreign yachts }\end{array}$ & Cruisers & $\begin{array}{c}\text { Cruise } \\
\text { passengers }\end{array}$ \\
\hline \hline 2007 & - & - & - & - & 174 & 45,653 \\
\hline 2008 & - & - & - & - & 245 & 50,554 \\
\hline 2009 & - & - & - & - & 268 & 70,749 \\
\hline 2010 & - & $1,758,692$ & 2,807 & 12,877 & 313 & 142,259 \\
\hline 2011 & - & $1,749,982$ & 2,964 & 13,977 & 319 & 187,171 \\
\hline 2012 & - & $1,227,877$ & 2,987 & 14,494 & 348 & 244,084 \\
\hline 2013 & - & $1,295,366$ & 3,786 & 15,778 & 409 & 314,961 \\
\hline 2014 & 107,814 & $1,241,431$ & 3,961 & 18,129 & 350 & 306,397 \\
\hline 2015 & 98,974 & $1,488,399$ & 4,018 & 20,859 & 411 & 441,513 \\
\hline 2016 & 110,127 & $1,645,797$ & 4,384 & 21,544 & 480 & 532,337 \\
\hline 2017 & 118,535 & $2,096,122$ & 4,598 & 23,001 & 430 & 540,445 \\
\hline 2018 & 98,455 & $1,963,204$ & 4,710 & 27,685 & 424 & 506,198 \\
\hline
\end{tabular}


In this section, the authors have elaborated the current situation of ship reporting formalities in Montenegro and have shown the desired state of the art for eMaritime services in Montenegro. Ultimately, the costs and benefits estimation of the NMSW implementation in Montenegro has been provided.

\subsection{Current situation of ship reporting formalities}

The process of reporting and clearance of ships calling at Montenegro ports is time-consuming for the shipmasters and ship agents. The shipmaster or ship agent should, for each port call, deliver in a paper form, via fax or e-mail, various documents to different authorities responsible for the ship clearance process. The pre-arrival documents are mainly sent electronically, while port documents are handed in paper form upon arrival. Also, ship masters with dangerous cargo on board transiting ADRIREP [53] Montenegro zone of responsibility are supposed to send information regarding dangerous cargo on board to the MRCC Bar via VHF.

The Law on Maritime Safety [54] requires the agent to electronically report the pre-arrival information 24 hours in advance to the Maritime Safety Department (MSD). The agent mostly reports safety-related information to the MSD, such as the NOA (Notice of Arrival), DGM (Dangerous Goods Manifest - FAL 7), ISPS (Ship pre-arrival security information form for all ships prior to entry into the port of Montenegro), Notification of ship-generated waste, BWR (Ballast water reporting form) and NOD (Notice of Departure). The requested forms should be delivered via e-mail as an XLS file in a specific template. Upon reception, the MSD forwards some of the data to other authorities. Information which is received from the MSD or directly from ship agents, are entered by port operators into their improvized systems (spreadsheet tables and/ or stand-alone applications) for their internal use and reporting; therefore, these systems could not be considered as legacy systems. The regulation of this Law [55] appoints the Harbour Master (HM) for issuing "Free Pratique" and "Permit of Vessel's Departure". The agent must electronically send to HM, 24 hours in advance for the arrival and 2 hours before for the departure, all FAL forms and MDH (Maritime Declaration of Health). Other authorities (Police, Health, Customs, etc.) also require reporting via e-mail in advance.
Before the ship arrives in one of the ports in Montenegro, the paper copies of various documents should be prepared by the ship crew, and delivered upon arrival to the authorities responsible for the ship clearance.

\subsection{Desired state of the art for eMaritime services}

Future NMSW in Montenegro should facilitate maritime traffic by simplifying and minimizing the formalities on arrival, stay and departure of ships in international voyages. It should also introduce electronic reporting, making paper reporting obsolete. The NMSW should be the foundation for the future eMaritime services, as presented in Figure 2.

A proposal of the system architecture for the NMSW implementation in Montenegro, as well as the initial steps and tools necessary for the NMSW implementation, are given in [56].

\subsection{Costs and Benefits estimation of NMSW implementation}

\section{Estimation of costs}

As a starting point for cost estimation for setting up and running an NMSW, Equation 1 will be used and its elements will be discussed.

For estimating the preparation costs $(P)$, MSD experience in the VTMIS project [57] will be used. The overall preparation expenditure for this project was 150,000 euro. The preparation funds covered all relevant studies, including a draft of the national VTMIS regulation and tender preparation. The same amount is proposed for the NMSW preparation. Also, it is recommended to plan the funds for two study visits to two EU countries. The visits are beneficial for people who will be leading the NMSW project implementation. It is also proposed that, along with the preparation expenses, the expenses of the Technical Assistance team should be included during the tendering process.

For the implementation of the NMSW, a turnkey solution for hardware, software and training is suggested. The estimation for equipment $\left(H_{0}\right)$, software $\left(S_{0}\right)$ and human resources costs $(M)$ is 500,000 euro [58]. Bearing in mind that, at the moment, there are no legacy systems in Montenegro that should be updated, the overall implementation costs are estimated at 500,000 euro. 


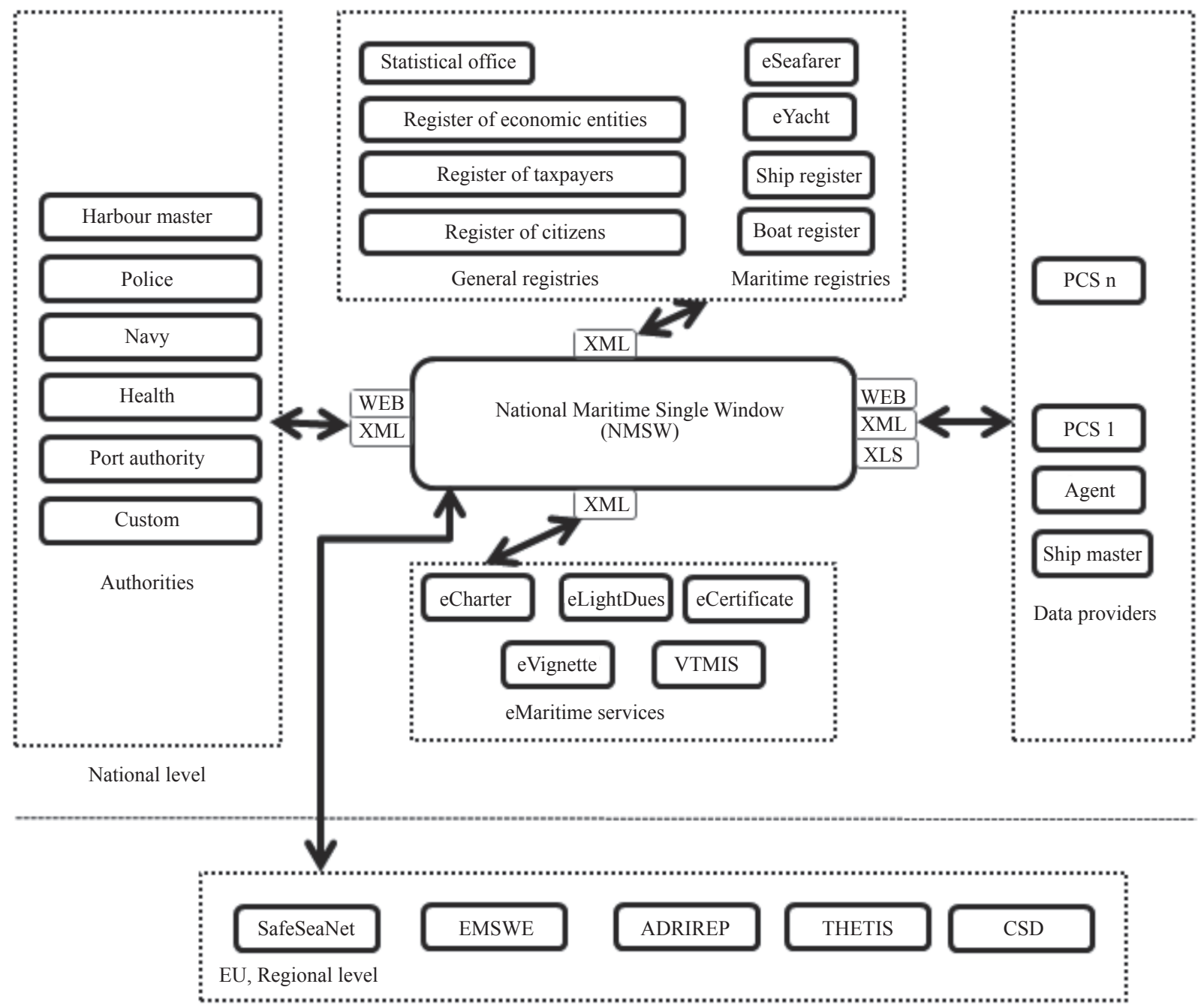

Figure 2 - TO-BE model of communication among stakeholders for ship clearance in Montenegro (authors)

The MSD (as future NCA for NMSW) already employs skilled staff for technical maintenance of VTMIS and ICT equipment. Following the scenario of VTMIS maintenance, it is suggested that the existing technical staff should be trained to carry out the first level support services. Costs of their additional training should be covered by the implementation budget. Same as for the implementation phase, a turnkey solution for the needed outsourced maintenance is suggested. If possible, one company should be a single point of contact for both hardware and software maintenance issues. The implementation of the VTMIS system was worth $1,800,000$ euro, while the yearly maintenance contracts, including spare parts, were 67,938.89 euro for the year 2018 [59] and 64,995.00 euro for the year 2019 [60]. For the year 2020, the deal of a total worth of $89,382.00$ euro will be signed [61]. It is possible to calculate that the mean value of the yearly maintenance contract with spare parts for the VTMIS system is $4.1 \%$ of the implementation costs.

The maintenance of VTMIS is more complex, bearing in mind different types of state-of-the-art telecommunication equipment, such as solid-state radars, direction finders, radio links, VHF and AIS transponders, etc., all positioned at locations with severe weather conditions (thunderstorms and lightning). The majority of corrective and preventive maintenance operations on the VTMIS system are performed by the MSD technical staff. The NMSW maintenance contract will most likely require fewer hardware interventions and will mostly be focused on software improvements and changes. The highly skilled team (such as developers) is needed, and for the time being, the MSD does not employ such staff [62]. It can be concluded that the maintenance contract shall not exceed $4.1 \%$ of the total value of implementation, which 
is 20,500.00 euro yearly. This figure is based upon the experience of MSD with VTMIS maintenance contracts in the last three years.

Finally, to determine the overall costs, NMSW life expectancy of 15 years is assumed. According to Equation 4:

$$
\begin{aligned}
C & =P+T+\sum_{i=1}^{N} R_{i}=150,000+500,000+15 \cdot 20,500= \\
& =957,500 €
\end{aligned}
$$

\section{Estimation of benefits}

To quantify the benefits of the NMSW implementation in Montenegro based on Equation 8, several things will be assumed:

1) The number of SOLAS ships calling at Montenegro ports is expected to be 1,000 on a yearly basis;

2) The lifecycle of the NMSW is 15 years;

3) To estimate the overall time that can be saved per ship call by using an electronic NMSW, the research results from [63] and [64] are used. Research in Croatia has shown 3.7 person-hours working time savings after reengineering the process "Vessel arrival to the port". Bearing in mind that the procedures for ship calls in Montenegro are similar to the ones used in Croatia, the research results from [63] and [64] can be used to quantify the benefits for Montenegro.

The average monthly gross salary in Montenegro in the "Transport and Storage" sector, according to the latest data from the Statistical Office of Montenegro is 812 euro [65]. The average price of the working hour $(p)$ can be obtained by dividing the gross average wage with 174 (the number of working hours in one month). Therefore, the average price of the working hour in the "Transport and Storage" sector in Montenegro is 4.67 euro per hour.

Bearing in mind the above assumptions, the overall quantitative benefit of the NMSW will be:

$$
\begin{aligned}
B & =N V p t_{d}=15 \cdot 1,000 \cdot \frac{3.7 x}{174 h} \cdot 812=15 \cdot 17,266.67= \\
& =259,000.00 €
\end{aligned}
$$

Apparently, the overall quantitative benefits are lower than the costs. Moreover, the quantitative benefits on a yearly basis are lower than the running costs of the system. It has to be noted that many topics in quantitative benefit estimation were not included. Only the benefits for SOLAS ships have been quantified. According to Table 1, there is a growing tendency of foreign yachts calling at Montenegro ports and marinas. Undoubtedly, if pleasure crafts are included in the NMSW, more savings in the working hours will be achieved, while revenues from Vignettes will be higher and more control on yacht rental will lead to more income for the country. Likewise, Montenegro will become more attractive as a yachting destination, owing to simplified and timely clearance procedures.

Advanced reporting, in combination with the VTMIS system, will help organize maritime traffic in congested areas like the Boka Bay. It will increase safety at sea and have an impact on reducing emissions. Police and customs will have the possibility to improve risk assessment and influence in mitigation of criminal activities that will decrease transport costs [38].

Light dues paid by commercial ships entering ports in Montenegro are a primary source of income for the MSD. Vessels can receive discounts depending on the number of entries in the Montenegro waters. The process of invoicing will be more transparent and with less workload, if eLightDues are introduced as a part of an NMSW in Montenegro. The pilot and tug service data exchange will be an added value for the system if pilots and tugs are incorporated in the NMSW. Moreover, pilot engagements could be cross-checked in advance with the seafarer database (eSeafarer module) if the appointed pilot has requested certificates for that area. The NMSW will imply shorter port time for the ships and shorter export/import delays in Montenegro. It will definitely position Montenegro economy higher in "Making Business reports" issued by the World Bank.

\section{CONCLUSION}

The NMSW facilitates communication among stakeholders in maritime trade and enhances maritime transport efficiency, safety, reliability, and security. Many developed countries have already implemented the NMSW, while in some regions, such as the EU, the NMSW has become mandatory. For further promotion of maritime trade facilitation and the use of standardized electronic systems for ship clearance at the global level, IMO has agreed to amend the FAL Convention and the NMSW has become mandatory since April 2019. This necessary system should at least cover the reporting documents included in the FAL Convention.

Previous research related to NMSW shows that previous papers and studies are mostly focused on ports or systems located in the developed countries. Little attention has been given to developing coastal 
states that have to fulfill the obligations stemming from the signing of the FAL convention. Thus, in this paper a comprehensive overview of the NMSW has been provided, as well as the cost-benefit analysis of the NMSW implementation, with the case study of Montenegro as a representative of a small developing country.

The main concern for the developing (and smaller) countries is the cost of the NMSW implementation, and the running costs afterward. Creating a Regional NMSW that could encompass the needs of several countries is one way of cost reduction. Such initiatives already exist in the Adriatic-Ionian Region, European Union (where direct benefits are estimated to be several times higher than the costs) and in some smaller developing island countries. However, regional and global Single Windows or cloud solutions pose a threat to data privacy. The issue of how to protect the commercial data will have to be addressed during the implementation. Moreover, in some countries such as Montenegro, it is forbidden for public servers of governmental entities to be located outside the country.

Regardless of all obstacles and expenses in the NMSW implementation, the NMSW can definitely be recommended for the smaller developing countries. In this paper, the economic benefits have been quantified such as the value of time and labour saved. Numerous other benefits that could not be quantified are mentioned, which can be subject to further research, such as the prevention of illegal activities and corruption, decrease in tax frauds and smuggling, and in this way, increasing revenues and overall efficiency.

It is important to simplify the national procedures and harmonize the reporting formalities at the national level before the NMSW implementation. The harmonization process is time-consuming, but it will enable the stakeholders (mainly the Ministry of Transport and Maritime Affairs of Montenegro and Maritime Safety Department) to fully benefit from the NMSW system. Not being a member of the EU, Montenegro has expressed interest to participate as observer in the Expert group on Maritime administrative simplification and electronic information services (eMS group), SafeSeaNet Group (managed by EMSA) and the High-Level Steering Group on SafeSeaNet (managed by the European Commission), by sending official request to the European Commission in 2014.
A large challenge is to introduce the NMSW in conjunction with the existing legacy ICT infrastructure. Transition economies and smaller countries, such as Montenegro, should have fewer issues with the legacy systems, because fewer legacy systems are implemented.

Finally, for tourism-dependent destinations such as Montenegro and numerous small developing countries, adding non-SOLAS vessels and pleasure crafts in the NMSW will provide added value, creating more income for the country. All this will lead to a higher ranking in the "Doing business" list, which is very important for countries that largely depend on foreign investments.

\section{ACKNOWLEDGEMENT}

This work has been supported by the Ministry of Science of Montenegro (INVO-HERIC National Excellence Scholarships), Administration for Maritime Safety and Port Management of Montenegro and the University of Rijeka, Croatia (under the Faculty of Maritime Studies projects).

Mr. sc. NEXHAT KAPIDANI, dipl. ing. el. ${ }^{1}$

E-mail: nexhat.kapidani@pomorstvo.me

Dr. sc. EDVARD TIJAN, izvanredni profesor ${ }^{2}$

E-mail: etijan@pfri.hr

MARIJA JOVIĆ, mag. ing. logist., doktorandica ${ }^{2}$

E-mail: jovic@pfri.hr

Prof. dr ENIS KOČAN, vanredni profesor ${ }^{3}$

E-mail: enisk@ucg.ac.me

${ }^{1}$ Uprava pomorske sigurnosti i upravljanja lukama Ul. Maršala Tita br. 7, pf. 14, 85000 Bar, Crna Gora

${ }^{2}$ Sveučilište u Rijeci, Pomorski fakultet

Studentska ulica 2, 51000 Rijeka, Hrvatska

${ }^{3}$ Univerzitet Crne Gore, Elektrotehnički fakultet

Dž. Vašingtona bb., 81000 Podgorica, Crna Gora

\section{JEDINSTVENI NACIONALNI POMORSKI PROZOR - ANALIZA TROŠKOVA I KORISTI NA STUDIJI SLUČAJA CRNE GORE}

\section{SAŽETAK}

U ovom radu istražuju se troškovi i koristi Jedinstvenog nacionalnog pomorskog prozora (NMSW) u obalnim državama koje imaju ograničene ljudske resurse $i$ infrastrukturu vezane za pomorski saobraćaj. Predložena je opšta metoda sprovođenja analize troškova i koristi prilikom uvođenja NMSW-a. Koristeći ovu metodu $i$ ulazne podatke za Crnu Goru, kao primjer male obalne države, autori procjenjuju može li ulaganje u primjenu NMSW-a biti korisno za obalne države koje raspolažu ograničenim resursima. 


\section{KLJUČNE RIJEČI}

Jedinstveni nacionalni pomorski prozor; analiza troškova i koristi; studija slučaja Crna Gora;

\section{DRITARJA UNIKE KOMB̈̈TARE NË DETARI - ANALIZA E SHPENZIMEVE DHE TË ARDHURAVE NË RASTIN STUDIMOR MALI I ZI}

\section{PËRMBLEDHJE}

Në këtë punim hulumtohen shpenzimet dhe të ardhurat e Dritares Unike Kombëtare të Detarisë (NMSW - National Maritime Single Window) në lidhje me komunikacionin detar në shtetet bregdetare të cilat kanë burime të kufizuara në njerëz dhe infrastrukturë. Është propozuar metoda e përgjithshme e zbatimit të analizës së shpenzimeve dhe të ardhurave në rastin e implementimit të NMSW-së. Duke shfrytëzuar këtë metodë dhe të dhënat hyrëse për Malin e Zi, si shembull i një shteti të vogël bregdetar, autorët vlerësojnë se a mund të jetë $i$ dobishëm investimi në implementim të NMSW-së për shtetet bregdetare me resurse të kufizuara.

\section{FJAL Ë KYÇE}

Dritarja Unike Kombëtare në Detari; analiza e shpenzimeve dhe të ardhurave; rasti studimor Mali i $\mathrm{Zi}$;

\section{REFERENCES}

[1] Šekularac-Ivošević S, Husić-Mehmedović M, Twrdy E. Repositioning strategy in the maritime port business: A case study from Montenegro, port of Adria. Promet Traffic\&Transportation. 2019;31(1): 75-87.

[2] Tijan E, Agatić A, Jović M, Aksentijević S. Maritime National Single Window - A Prerequisite for Sustainable Seaport Business. MDPI Sustain. 2019;11(17): 1-21.

[3] African Alliance for e-Commerce. Single Window as an Enabler for e-Commerce Development; 2017. Available from: https://unctad.org/meetings/en/Presentation/dtl eWeek2017p61_AbdoullahiFaouzi_en.pdf [Accessed: 07-Jun-2019].

[4] Maritime Sector. 2019. Available from: http://www. windrosenetwork.com/Maritime-Sector [Accessed 04 Mar 2019].

[5] Kos S, Vukić L, Brčić D. Comparison of External Costs in Multimodal Container Transport Chain. Promet Traffic\&Transportation. 2017;29(2): 243-252.

[6] UNCTAD. Review of Maritime Transport; 2019. Available from: https://unctad.org/en/PublicationsLibrary/ rmt2019_en.pdf [Accessed 24 Jan 2020].

[7] Beškovnik B, Twrdy E. Agile Port and Intermodal Transport Operations Model to Secure Lean Supply Chains Concept. Promet - Traffic\&Transportation. 2011;23(2): 105-112.

[8] Contribution of the International Maritime Organization to the UN Secretary-General's Report on Oceans and the Law of The Sea Preliminary Considerations. Available from: http://www.un.org/depts/los/general_assembly/ contributions_2018/IMO.pdf [Accessed 5 Feb 2019].

[9] International Maritime Organization. FAL Convention. 1965. Available from: http://www.imo.org/en/OurWork /Facilitation/ConventionsCodesGuidelines/Pages/ Default.aspx [Accessed 7 Aug 2019].

[10] International Maritime Organization (IMO). Contracting states to IMO FAL Convention. 2020. Available from: https://gisis.imo.org/Public/ST/Treaties.aspx [Accessed 30 Jan 2020].

[11] International Maritime Organization (IMO). Electronic information exchange mandatory for ports from 8 April 2019. 2019. Available from: http://www.imo.org/en/ MediaCentre/PressBriefings/Pages/06-electronicinformation-exchange-.aspx [Accessed 06 Aug 2019].

[12] Tijan E, Jardas M, Aksentijević S, Perić Hadžić A. Integrating Maritime National Single Window with Port Community System - Case Study Croatia. In: $31^{\text {st }}$ Bled eConference - Digital Transformation: Meeting the Challenges Conference Proceedings, Bled, Slovenia. 2018. p. 1-11.

[13] International Maritime Organization. Guidelines for Setting up a Maritime Single Window, FAL.5/Circ.42. 2019. Available from: http://www.imo.org/en/OurWork/ Facilitation/docs/FAL\%20related\%20nonmandatory \%20instruments/FAL.5-Circ.42.pdf [Accessed 6 Aug 2019].

[14] Lambrou MA, Rødseth ØJ, Foster H, Fjørtoft K. Service-oriented computing and model-driven development as enablers of port information systems: An integrated view. WMU Journal of Maritime Affairs. 2013;12(1): 41-61. Available from: https://link.springer. com/article/10.1007\%2Fs13437-012-0035-0 [Accessed 6 Aug 2019].

[15] McMaster J, Nowak J. The Evolution of Trade Portals and the Pacific Islands Countries E-Trade Facilitation and Promotion. Electronic Journal of Information Systems in Developing Countries. 2006;26(1): 1-27.

[16] Sanchez-Gonzalez PL, Díaz-Gutiérrez D, Leo TJ, Núñez-Rivas LR. Toward Digitalization of Maritime Transport? MDPI Sensors. 2019;19(4). Available from: https://www.mdpi.com/1424-8220/19/4/926 [Accessed 6 Aug 2019].

[17] Hossain SA. Blockchain computing: Prospects and challenges for digital transformation. In: $20176^{\text {th }}$ International Conference on Reliability, Infocom Technologies and Optimization: Trends and Future Directions, ICRITO 2017; 2018. p. 61-5.

[18] Ullah I, Ahmad S, Mehmood F, Kim D. Cloud Based IoT Network Virtualization for Supporting Dynamic Connectivity among Connected Devices. MDPI Electronics. 2019;8(7). Available from: https://www.mdpi.com/20799292/8/7/742/htm [Accessed 6 Aug 2019].

[19] Linkov I, Trump BD, Poinsatte-Jones K, Florin MV. Governance strategies for a sustainable digital world. MDPI Sustainainability. 2018;10(2). Available from: https://www.mdpi.com/2071-1050/10/2/440 926 [Accessed 6 Aug 2019].

[20] Rodríguez-Rodríguez I, Zamora-Izquierdo MÁ, Rodríguez JV. Towards an ICT-based platform for type 1 diabetes mellitus management. MDPI Applied Sciences. 2018;8(4). Available from: https://www.mdpi.com/2076- 
3417/8/4/511 [Accessed 6 Aug 2019].

[21] Bauk S, Draskovic M, Schmeink A. Challenges of Tagging Goods in Supply Chains and a Cloud Perspective with Focus on Some Transitional Economies. Promet Traffic\&Transportation. 2017;29(1): 109-120.

[22] The Single Window concept. Available from: http://tfig. unece.org/contents/single-window-for-trade.htm [Accessed 28 Feb 2019].

[23] World Customs Organization. The Single Window Concept: The World Customs Organization's Perspective. Available from: http://www.wcoomd.org/ /media/wco/ public/global/pdf/topics/facilitation/activities-andprogrammes/tf-negociations/wco-docs/info-sheets-on-tfmeasures/single-window-concept.pdf [Accessed 7 Jun 2019].

[24] United Nations. Trade facilitation - principles and benefits. Available from: http://tfig.unece.org/details.html [Accessed 10 Jun 2019].

[25] UNCTAD. Different types of National Trade Facilitation Bodies. Available from: https://unctad.org/en/DTL/TLB/ Pages/TF/Committees/NTFB_background.aspx [Accessed 15 Mar 2019].

[26] Nowak J. The Evolution of Electronic Trade Facilitation: Towards a Global Single Window Trade Portal. Available from: https://www.researchgate.net/publication/228581401_The_Evolution_of_Electronic_Trade Facilitation_Towards_a_Global_Single_Window Trade_Portal [Accessed 15 Mar 2019].

[27] The Progress of Thailand National Single Window. 2019. Available from: http://www.thainsw.net/INSW/index. jsp?nswLang=E [Accessed 24 Jun 2019].

[28] General Department of Customs and Excise of Cambodia. National Single Window: Cambodia. 2019. Available from: http://www.customs.gov.kh/trade-facilitation/ national-single-window/ [Accessed 22 May 2019].

[29] Niculescu MC, Minea M. Developing a Single Window Integrated Platform for Multimodal Transport Management and Logistics. Transportation Research Procedia. 2016;14: 1453-62. Available from: http://dx.doi.org/ 10.1016/j.trpro.2016.05.219 [Accessed 22 May 2019].

[30] World Customs Organization. Going beyond the national Single Window. 2018. Available from: https:// mag.wcoomd.org/magazine/wco-news-87/goingbeyond-the-single-window/ [Accessed 24 Jun 2019].

[31] European Maritime Safety Agency. Operational Projects - European Maritime Single Window (EMSW). Available from: http://www.emsa.europa.eu/related-projects/emsw. html [Accessed 23 May 2019].

[32] EUR-Lex. Proposal for a REGULATION OF THE EUROPEAN PARLIAMENT AND OF THE COUNCIL establishing a European Maritime Single Window environment and repealing Directive 2010/65/EU. 2018. Available from: https://eur-lex.europa.eu/legal-content/ EN/TXT/?uri=CELEX\%3A52018PC0278 [Accessed 7 Jun 2019].

[33] EuropeanCommission.EuropeanMaritimeSingleWindow environment. 2019. Available from: https://ec.europa.eu/ transport/modes/maritime/digital-services/e-maritime_nl [Accessed 7 Jun 2019].

[34] Safety at Sea. Era of mandatory digital data exchange dawns on global ports. 2019. Available from: https:// safetyatsea.net/news/2019/era-of-mandatory-digital-data-exchange-dawns-on-global-ports/ [Accessed 24 Jun 2019].

[35] Rødseth ØJ, Kapidani N. A Taxonomy for Single Window Environments in Seaports. In: Proceedings of the $5^{\text {th }}$ International Maritime-Port Technology and Development Conference, Singapore; 2017. p. 271-83.

[36] PCS / Port Community Systems - IPCSA International. Available from: https://ipcsa.international/pcs [Accessed 22 May 2019].

[37] International Maritime Organization. FAL Convention: What is it? Why does it matter? Why should you care? Available from: http://www.imo.org/en/MediaCentre/ HotTopics/Documents/IMO - FAL Flyer hi-res single3. pdf [Accessed 11 Oct 2019].

[38] Clark X, Dollar D, Micco A. Port Efficiency, Maritime Transport Costs and Bilateral Trade. Journal of Development Economics. 2004;75(2): 417-450.

[39] UN/CEFACT. Case Studies on Implementing a Single Window. Available from: https://www.unece.org/fileadmin /DAM/cefact/single_window/draft_160905.pdf [Accessed 8 Sep 2019].

[40] Gartner IT Glossary. Hardware maintenance and support services. Available from: https://www.gartner.com/ it-glossary/hardware-maintenance-and-support-services [Accessed 6 Aug 2019].

[41] Doing Business. Trading Across Borders: Technology gains in trade facilitation. 2017. Available from: https:// www.doingbusiness.org/content/dam/doingBusiness/ media/Annual-Reports/English/DB17-Chapters/DB17CS-Trading-across-borders.pdf [Accessed 6 Aug 2019].

[42] The United Nations Centre for Trade Facilitation and Electronic Business (UN/CEFACT). Recommendation and Guidelines on establishing a Single Window to enhance the efficient exchange of information between trade and government. Recommendation No. 33. New York and Geneva: United Nations; 2005. Available from: www.unece.org/cefact [Accessed 6 Aug 2019].

[43] COMCEC. Single Window Systems Conceptual Framework and Global Trends and Practices. OIC study. 2017. $9^{\text {th }}$ Meeting of the COMCECTrade Working Group 2017. Available from: http://www.comcec.org/en/wp-content/ uplo-ads/2017/03/9-TRD-PRE-2.pdf [Accessed $10 \mathrm{Jul}$ 2019].

[44] University of Greenwich. Coordinated border management: Central America (Consultancy Project for the Inter-American Development Bank). 2019. Available from: https://www.researchgate.net/publication/335432763 Consultancy_Project_for_the_IDB_-_Coordinated_ Border_Management [A-Accessed 7 Aug 2019].

[45] United Nations. United Nations Centre for Trade Facilitation and Electronic Business. Paperless Trade in International Supply Chains: Enhancing Efficiency and Security. $3^{\text {rd }}$ Executive Forum on Trade Facilitation; 2005.

[46] UNCTAD. United Nations Conference on Trade and Development, Review of Maritime Transport. 2016. Available from: https://unctad.org/en/PublicationsLibrary/ rmt2016_en.pdf [Accessed 7 Aug 2019].

[47] The World Bank. Doing Business 2017: Equal Opportunity for All. 2017. Available from: https://www. doingbusiness.org/content/dam/doingBusiness/media/ 
Annual-Reports/English/DB17-Report.pdf [Accessed 7 Aug 2019].

[48] Montenegro. Odluka Vlade Crne Gore o određivanju luka prema značaju. Available from: http://www. luckauprava.gov.me/direktor/Luke_od_nacionalnog_ znacaja [Accessed 29 Aug 2019].

[49] Montenegro. Izvještaj o radu i stanju u upravnim oblastima Ministarstva saobraćaja $i$ pomorstva $i$ organa $u$ sastavu za 2018. godinu. Available from: http://www. msp.gov.me/ResourceManager/FileDownload.aspx?rid=353945\&rType $=2 \&$ file=Izvjestaj o radu MSP za 2018.pdf [Accessed 26 Aug 2019].

[50] Statistical Office of Montenegro. Godišnja statistika saobraćaja, skladištenja $i$ veza. 2018. Available from: http://monstat.org/ userfiles/file/saobracaj/2018/PUBLIKACIJA - GODISNJA STATISTIKA SAOBRACAJA 2018-cg. pdf [Accessed 8 Sep 2019].

[51] Statistical Office of Montenegro. Kružna putovanja stranih brodova u Crnoj Gori-Saopštenja. 2018. Available from: http://monstat.org/cg/page.php?id=634\&pageid $=588$ [Accessed 8 Sep 2019].

[52] Statistical Office of Montenegro. Godišnja statistika saobraćaja, skladištenja i veza - konačni podaci. 2018. Available from: https://www.monstat.org/cg/page.php?id $=1420 \&$ pageid $=36$ [Accessed 8 Sep 2019].

[53] International Maritime Organization. RESOLUTION MSC.139(76) (adopted on 5 December 2002): MANDATORY SHIP REPORTING SYSTEMS. 2002. Available from: http://www.imo.org/en/KnowledgeCentre/ IndexofIMOResolutions/Maritime-Safety-Committee -\%28MSC\%29/Documents/MSC.139\%2876\%29.pdf [Accessed 12 Aug 2019].

[54] Montenegro. Zakon o sigurnosti pomorske plovidbe, as amended. Montenegro; 2013.

[55] Montenegro. Ordinance on the manner of announcing the arrival of the vessel in the port and the departure of the vessel from the port. Available: https:// www.luckakapetanija.me/index.php?option=com phocadownload\&view $=$ category\&id=9:pravilniki-obrasci-za-najavu-dolaska-brodova-u-luku-i-odlaskabrodova-iz-luke\&Itemid=680 [Accessed 26 Aug 2019].

[56] Kapidani N, Kocan E. Implementation of national maritime single window in Montenegro. In: $23^{\text {rd }}$ Telecommunications Forum Telfor (TELFOR) 2015, Belgrade, Serbia; 2015.

[57] Standard Summary Project Fiche-IPA centralised programmes, Project Fiche: 7. Available from: https://ec. europa.eu/neighbourhood-enlargement/sites/near/files/ pdf/montenegro/ipa/2011/pf_7_ipa_2011_vtms.pdf [Accessed 12 Aug 2019].

[58] Montenegro. Transport Development Strategy - Montenegro 2019-2035. Available: http://www.msp.gov.me/ ResourceManager/FileDownload.aspx?rId=369086\&rType $=2$ [Accessed 8 Sep 2019].

[59] Montenegro. Tenderska dokumentacija broj: 1573/17 za Otvoreni postupak javne nabavke. Available from: http://portal.ujn.gov.me/delta2015/search/displayNotice. html? locale $=$ sr\&id $=114336 \&$ type $=$ InvitationPublicProcure\& [Accessed 26 Aug 2019].

[60] Montenegro. Tenderska dokumentacija broj: 1733/18/6 za Otvoreni postupak javne nabavke. Available from: http://portal.ujn.gov.me/delta2015/search/ displayNotice $\cdot \mathrm{htm}$ l locale $=\mathrm{sr} \& \mathrm{id}=120897 \&$ type $=$ InvitationPublicProcure\& [Accessed 26 Aug 2019].

[61] Montenegro. Odluka o izboru najpovoljnije ponude za nabavku djelova i održavanje VTMIS opreme za 2020 godinu. Available from: http://portal.ujn.gov.me/delta2015/search/displayNotice.html?id=126811\&type= InvitationPublicProcure [Accessed 27 Oct 2019].

[62] Montenegro. Pravilnik o unutrašnjoj organizaciji $i$ sistematizaciji uprave pomorske sigurnosti $i$ upravljanja lukama. Available from: http://www.gov.me/ ResourceManager/FileDownload.aspx?rId=358845\&rType $=2$ [Accessed 26 Aug 2019].

[63] Tijan E. Integral model of Electronic Data Interchange in seaport cluster. $\mathrm{PhD}$ thesis. University of Rijeka; 2012.

[64] Tijan E, Agatić A, Hlača B. The Necessity of Port Community System Implementation in the Croatian Seaports. Promet - Traffic\&Transportation. 2012;24(4): 305-315.

[65] Montenegro. Bruto zarade po sektorima djelatnosti. Available from: https://www.monstat.org/userfiles/ file/zarade/2018/Bruto zarade po sektorima djelatnosti 2012-2017.xls [Accessed 26 Aug 2019]. 